\title{
Children and War: How "Soft" Research Can Answer the Hard Questions in Political Science
}

\author{
Christopher Blattman
}

\begin{abstract}
Forgetting Children Born of War: Setting the Human Rights Agenda in Bosnia and Beyond. By R. Charli Carpenter. New York: Columbia University Press, 2010. 304p. \$35.00.
\end{abstract}

They Fight Like Soldiers, They Die Like Children: The Global Quest to Eradicate the Use of Child Soldiers. By Romeo Dallaire. New York: Walker \& Company, 2011. 320p. \$26.00.

Child Soldiers in the Age of Fractured States. Edited by Scott Gates and Simon Reich. Pittsburgh: University of Pittsburgh Press, 2010. 352p. \$27.95.

$\Lambda$ $s$ a graduate student, two months shy of defending my dissertation proposal, I yanked a first, respectable rough draft off my advisers' desks and replaced it with something completely new: a pitch to head to Uganda and start a study of child soldiering. My advisers were unimpressed. "This sounds more like a policy report than a dissertation," said one, "I'm not sure you should go." No one disagreed the issue was important. But is tackling a humanitarian issue the sensible start for a budding social scientist? It's a question young earnest scholars ask themselves every year: Can I get my Ph.D. and still save the world?

As it happened, there was more to my pitch. Buried inside the proposal, hidden to me at the time, was the germ of actual social science, something more than a policy report. Ultimately, the study would change the way I think about fundamental questions in international relations and comparative politics: the organization of rebellion, the diffusion of international norms, and the legacy of political violence on economic and political development. Big questions, I discovered, get answered in unusual places.

For the academic who tackles policy questions or humanitarian issues, the real world impact can be its own reward.

Christopher Blattman is Assistant Professor of Political Science at Yale University (christopher.blattman@yale.edu). He is grateful to Charli Carpenter, Scott Gates, Benjamin Morse, and Simon Reich for comments on drafts of this essay. Earlier discussions with Jeannie Annan, Jo Becker, Radikha Coomaraswamy, and Timothy La Rose were immensely helpful as well.
If that means sacrificing "serious" scholarship, some say, then so be it. I think that trade-off, however, is false and misleading. It leads to narrow and disjointed scholarship. Policy and science both suffer when the links to theory and big questions are ignored.

The three books under review here all tackle a topicchildren in war-with glaring moral consequence. Each book manages to avoid most of the myths and clichés that surround their lurid subjects. And each book delivers original and overlooked lessons for the problems facing waraffected children. But perhaps most important, each book contains lessons for our larger understanding of warfare and the politics of advocacy and aid.

These larger lessons, however, can struggle to emerge, for issues of great moral consequence can also obscure. Child soldiers and children born of wartime rape are as vivid, wrenching, and sensational as any subject in our profession. Speaking from my own experience, one struggles constantly with the scholarly disposition. On the one hand, keeping such a stance is hard. Field research brings emotional anguish and helplessness, and dealing with inert bureaucracies and injustice brings fury and despair. More importantly, it becomes difficult to separate advocacy from critical thought; sensational images and banal policyspeak too easily substitute for facts. On the other hand, it is also a struggle to escape the scholar's disposition. You catch yourself speaking of genocide or child abduction as variables and forgetting they are atrocities. More seriously, you become stuck in arcane details and arguments, and in fighting myths and sensation you can find yourself more callous and petty than objective and insightful. Neither circumstance does the victims, policy, or science the service each deserves. 
This struggle - to get beyond sensation to facts, and to find the balance between passion and dispassion-is apparent in all three books. Each transcends. Two of the books, R. Charli Carpenter's Forgetting Children Born of War and Scott Gates and Simon Reich's anthology Child Soldiers in the Age of Fractured States, push social scientists into a realm mostly populated by activists and practitioners. Carpenter looks at the politics of victimhood and aid: who gets money and attention and who does not. She puzzles why one group in particular-children born of wartime rape in Bosnia-received enormous media attention but little formal advocacy or services. Dissatisfied with the usual technocratic explanations, she tries to bare the mindsets, politics, and social forces that shape (and subvert) seemingly benign humanitarian agendas.

Gates and Reich tackle the opposite challenge: how to bring more rigorous research into an advocacy movement overwhelmed with its own success — eradicating child soldiers. The assembled essays reexamine the causes, conduct, and consequences of child soldiering, and ask what we learn that might help end the practice. As in any edited volume, we hear a cacophony of voices and views. Nevertheless, scholars of warfare will find in here vital lessons for what is a major frontier in the field: rebel strategy, organization, operations, and governance.

The third book, They Fight Like Soldiers, They Die Like Children, by Romeo Dallaire, pushes a soldier and advocate into the realm of the academic. Dallaire is a retired Lieutenant-General from the Canadian Armed Forces, and now sits in the Canadian Senate, but is best known for his role as Commander of the United Nations (UN) peacekeeping force during the Rwandan genocide. His rebirth as an advocate for ending child soldiering pushed him into a research collaboration with the political science department at Dalhousie University. His book is a massmarket effort at distilling lessons and pushing a policy agenda. For a profession so concerned with explaining order and violence, we hear awfully little from the men and women in charge of keeping the peace. As with the contributions to the Gates and Reich volume, social science mixes with some of the myths and hyperbole surrounding children in war, but Dallaire still offers scholars astute insights on armed groups and the future of warfare.

\section{A Primer on Children in War}

The plight of children in war is appalling. Their schools and homes are destroyed, or their parents killed. They may be the last to receive scarce food or medicine. They are killed in crossfire, attacks, and (more recently) by drones. Women and girls are sexually assaulted and, as if that is not horror enough, they and the children born of these rapes could be traumatized or stigmatized for life.

The most visible child in war, however, is undoubtedly the child soldier. We are all familiar with the image: a young boy, invariably black or brown, carrying an AK- 47 and slung with bandoliers. No news article or book on the subject is complete without this iconic image. Child soldiers have captured special media and Hollywood attention. In 2006 the release of a feature film, Blood Diamond, as well as a documentary, Invisible Children, spawned an American movement of tens of thousands of concerned students, lobbying for Congressional action against child recruitment in Uganda. By 2007 you could buy the memoirs of a boy soldier with your Starbucks coffee. Subsequent years saw a comic book series launched, several popular novels, and innumerable documentaries, including an Academy Award nominee, War Dance. In 2011, the film Machine Gun Preacher told the true(ish) story of an American ex-gang member rescuing child recruits from armed groups in South Sudan. Finally, in 2012, Invisible Children's Kony 2012 campaign became the most viral video in the history of the Internet. I cannot think of another "child protection" issue that comes close to the same media attention.

Fortunately, more than simply a success as an American pop icon, the campaign against child soldiering has been a diplomatic and advocacy success as well. A relatively obscure issue in the early 1990s, it entered the UN Security Council's focus in the mid-1990s, and a decade later nearly every state in the world had agreed not to recruit (or at least use in combat) children under eighteen, and certainly not under fifteen. ${ }^{1}$ The International Criminal Court (ICC) treats the use of child soldiers under 15 as a war crime, and it is the main charge against Thomas Lubanga, the former rebel leader in the Democratic Republic of Congo, in the ICC's first case. It is also a central charge in the Special Court of Sierra Leone's pursuit of Liberian ex-President Charles Taylor. A special UN representative for children and armed conflict was created in 1997, and has been highly influential in ending state recruitment through negotiation and, where necessary, naming and shaming. For the most part, child soldiering is now solely the province of non-state armed groups, and even here the UN special representative has begun to engage many forces in discussion. ${ }^{2}$

Without question, child soldiering persists. No one has an accurate count. Numbers like 200,000 or 300,000 have been tossed about since the 1990s, based mainly on guesswork, with obscure origins. These figures soon achieved the status of fact, and the number persists in newspapers and advocacy literature. Probably the number of children in armed groups has gone down in the last 10 years, if only because of the steep decline in the number and intensity of wars, especially the decline or defeat of the forces most notorious for their use, such as the Lord's Resistance Army in Uganda, or the Tamil Tigers in Sri Lanka. ${ }^{3}$ No one knows. But armed groups in 21 countries still recruited children the last time a systematic count was made, between 2004 and $2007 .{ }^{4}$ In the past year, there are signs that children continue to be recruited in a familiar list of fragile states, including Afghanistan, Iraq, eastern Congo, South 
Sudan, Darfur, and Somalia. ${ }^{5}$ New conflicts in 2011 also brought worrying reports of new child recruitment, including Côte d'Ivoire and Libya.

Why did the norm against child soldiering rise so suddenly and, by some measures, successfully? There seems to be something deeply salient about the idea of the child recruit. Few issues invoke more horror or fascination. This salience undoubtedly helped launch the issue onto the global stage. Yet other sensational, evil acts abound-like children born of genocidal rape-and yet (as Carpenter argues) these issues have not received the same attention from international organizations. Why is that? What does this tell us about the state of international advocacy and the politics of policy-making?

This is the question posed by Charli Carpenter. Before tackling it, however, it's worth engaging the two volumes on child soldiers. With iconic status have come iconic images and ideas. Perhaps the most common image is that of the traumatized youth returned from battle, or the girl stigmatized and scorned for her rape by rebels. "They are walking ghosts," mourned a 2006 New York Times editorial, "damaged, uneducated pariahs." While mourning this human tragedy, policymakers also fear that former child fighters pose a risk to security. In 2007, the French foreign minister warned that child soldiers are "a time bomb that threatens stability and growth in Africa and beyond." They are "lost children," he argued, "lost for peace and lost for the development of their countries" "Child Soldiers 'are a time bomb." BBC News, February 5, 2007).

Finally, the child soldier is seen as emblematic of the new barbaric nature of war, and the depraved greed or madness that leads armed leaders to recruit the most innocent. The idea of this "new kind of war" - senseless, purposeless, criminal, and barbaric — was firmly planted by eminent journalists like Robert Kaplan and Jeffrey Gettleman and bolstered by civil war scholars like Mary Kaldor and Carolyn Nordstrom. ${ }^{6}$ The journalists were especially influenced by their exposure to wars with heavy numbers of child recruits, from Liberia to northern Uganda. These West and East African wars, and the issue of child soldiering (along with wartime rape and civilian abuse), have shaped our conception of modern civil war to an amazing and unappreciated degree.

What is troubling is that we have very little evidence that any of these iconic ideas and conventional wisdoms are true. As we will see, the evidence is growing that they are exaggerated or even misleading, not only distorting policy, but hindering our larger understanding of who recruits, who rebels, and why.

\section{The Conference of Scholars: The Gates and Reich Volume}

I have made out the crusade against child soldiering to be a success. Gates and Reich are less sanguine. Indeed, they motivate their volume on the meager effect of public pressure on non-state recruitment of children. Compared to other advocacy movements, they argue, child soldiering has enjoyed few tangible results. ${ }^{7}$ Not all the contributors share this view. Chapter 3, by Tonderai Chikuhwa, emphasizes the rapid pace of progress, especially by UN Security Council standards. ${ }^{8}$ Whether the pace of change has been fast or slow is partly subjective. Compared to the campaign against human trafficking, child soldiering has certainly been less successful at eradication. ${ }^{9}$ And they are right to decry the slow and so far unproductive attempt to prosecute offenders, an issue I'll return to later.

The editors' disappointment may also reflect the timing of the discussion that led to the book-a set of conferences in 2006 — and the fact that most of the cases and data come from years before (or during) the unprecedented decline of civil wars in the years 1999 to 2005 - a trend not fully appreciated until some years afterwards. ${ }^{10}$ Not only have civil wars become fewer and smaller, but the UN's special representative for children and armed conflict has recorded many more successes in engaging non-state groups in dialogue since 2006 than before, when the office focused mainly on government forces. ${ }^{11}$ One of the troubles with so much policy-relevant research (and here I am as much an offender as any) is the long lag to publication, a problem augmented by the speed of the academic press. This may be one reason why myths persist.

Nonetheless, Gates and Reich are right: non-state armed groups and a few rogue regimes persist in child recruitment. To understand why, they bring together a large group of contributors who deliver a number of high-quality case studies of groups, histories of children in war, some rare survey data, and scrutiny of failed and successful policies.

Like many edited volumes, at first glance the chapters resemble a motley collection of well-crafted but disjointed parts. P.W. Singer, for instance, explains the rise of child soldiering in the late twentieth century by the expansion of light arms, disrupted economies, and the deterioration of social norms against child enlistment. ${ }^{12}$ Two chapters (one by Vera Achvarina and Simon Reich looking crossnationally, and one by Sarah Kenyon Lischer looking at the Democratic Republic of the Congo) argue that refugee and displacement camps, with their meager military protection and horrible living standards, are prime recruiting grounds for both forced and voluntary recruitment. Country case studies by James B. Pugel (on Liberia), Jo Becker (Burma, Sri Lanka, and Nepal), and Francisco Gutiérrez Sanín (Colombia) illustrate how the ease of child indoctrination is central to recruitment.

The parts are not so much disjointed, however, as simply reflecting diverse and sometimes conflicting views. Moreover, the book contains foundations for a larger, more coherent structure-possibly even a unifying theory. This comes in chapter 5 by Jens Christopher Andvig and Scott Gates, who frame the recruitment question and policy solutions in plain labor supply and demand. Their goal is to illuminate the "market" for child soldiers. 
One gets the sense that Andvig and Gates bring in the language of labor economics reluctantly, perhaps for fear of confusing a non-technical audience (and, I gather, because the approach met with open hostility and rage). But I think the model is a hugely important one, one that illuminates rebel recruitment more generally, and deserves to be outlined more explicitly.

In standard labor economics, the quantity of labor demanded by firms is an array of different quantities desired at different prices. The demand function arises from the value firms place on the work performed-the marginal product of labor. This labor demand is often depicted in a two-by-two graph with price on the vertical axis and quantity on the horizontal. The labor demand curve slopes downwards, as more labor is demanded at lower prices. Meanwhile, the standard labor supply curve is a function of the reservation wage (the intercept) and the slope and curvature is driven by the relation between the responsiveness (elasticity) of laborers to wages. It is an aggregation of individual decisions over labor versus leisure. It could be upward sloping, as is conventional, or it could be flat, as in the famous W. Arthur Lewis model of "unlimited labor" in developing countries. ${ }^{13}$

On the face of it, it might seem callous, absurd, or simply inappropriate to think of acts like child punishment and abduction in terms of this model of free labor. But let us hold that thought momentarily, and see where the model takes us.

Imagine a segmented labor market, with two labor demand functions: one for children and one for adults, driven by their different marginal productivities. What happens with the introduction of cheap and light weaponry? Both adults and children become more productive, but children disproportionately so, for they could not handle previous weapons. The demand curve steepens and shifts to the right, increasing the quantity of children demanded relative to adults. If (as some assume) the labor supply of children is flatter than that of adults, because they are plentiful, or because war destroys their educational opportunities and basic food or shelter, that quantity demanded could rise dramatically.

Alternatively, consider the effect of a group with a strong religious, ethnic, or other ideological appeal, or set of skills in indoctrination and information control. To the extent they can use these skills and messages to elicit higher commitment and performance, labor demand steepens and shifts out again-more so for children if they are indeed more susceptible to indoctrination. Meanwhile, to the extent that ideology provides non-pecuniary benefits to recruits, like self or group esteem, the reservation wage will fall and the labor supply will become more elasticagain disproportionately among children.

This framing is helpful because, one by one, the varied explanations for child soldiers fall into place in this simple framework. In some sense, it provides a unifying frame- work. It also helps avoid confusing statements (seen elsewhere in the volume) that children are attractive recruits because they "come on the cheap." 14 For the "price" of children is not a given condition of the environment but rather an equilibrium outcome of supply and demand, and the forces beneath. As I've argued in a paper with Bernd Beber, children will not always and everywhere be inexpensive. ${ }^{15}$

The model is further helpful as a guide to predict where and when child soldiering will occur, based on available technologies and modes of rebellion (which drive child versus adult productivity) or labor conditions. It also helps explain seemingly barbaric tactics, like massacres and displacement (which reduce the returns to non-rebellious labor) or forcing recruits to commit acts of violence (which lower reservation wages, out of fear that they can never return home). Thus, the barbaric act suddenly reveals itself as cruelly calculating. This reframing is important. If child recruiters are mad men, our options are few. But if they are self-interested and calculating leaders simply responding to incentives and constraints, suddenly a world of policy and counter-insurgency options is exposed.

Indeed, this simple model suddenly tells us how we can think about many of the policy prescriptions throughout the book. Armed protection of children (as argued in chapter 4 by Achvarina and Reich) or "child friendly spaces" (as advocated in chapter 13 by Maureen W. McClure and Gonzalo Retamal) shift the supply curve to the left, and the availability of schools, jobs, or simply food and shelter steepen the supply curve dramatically. Punishment of leaders in international courts, or by concerned citizens, diasporas, or donors who withhold their material support from abusive groups lower the child's marginal product of labor relative to adults.

My only lament is that a model like this one was not used as an organizing framework for the whole volume. To do so, however, would likely have alienated or enraged the policy audience and participants, as even that sole chapter created discord in the group. ${ }^{16}$ The policyrelevant researcher must keep watch on all sides.

Nevertheless, political science is on the cusp of a more structured and formal understanding of the "industrial organization of rebellion." For two decades our understanding of armed groups and violent participation has advanced mainly when scholars integrate deep case and qualitative knowledge with insights from agency theory. Mark Lichbach promoted the idea of the rational peasant who required selective incentives to solve the collective action problem inherent in popular revolt. Elisabeth Wood illustrated that selective incentives need not be material, and that ideology and injustice can strongly motivate participation. Scott Gates noted that the leader's challenge in rebellion is not merely motivating participation (the collective action problem) but also motivating performance, and framed the challenges in a more formal 
principal-agent logic with imperfect information. Jeremy Weinstein's study of Ugandan and Peruvian armed groups illustrated the impact that the consequent moral hazard and adverse selection play in determining recruitment and control strategies, and the impact on civilian abuse and other insurgent behavior. Bernd Beber and I extend this principal-agent approach to understand coercion and child recruitment, and why the two go hand in hand. ${ }^{17}$

These increasingly theoretical and formal analyses have been valuable precisely because they have provided coherent and testable explanations for seemingly puzzling rebel behavior. Weinstein, for instance, shows how abundant material resources and weak ideological appeal or social bases of support lead to an adverse selection problem in recruitment, and with it an opportunistic and violent army with few incentives for restraint against civilians. Gates' earlier work in 2002 brings in the contest element of civil war and illustrates how this information problem is amplified by geography. ${ }^{18}$ Formalizing the logic in models, moreover, has not made these theories more material. Indeed, if anything, they have strengthened the case that non-pecuniary incentives-injustice, ideology or indoctrination-matter most of all.

Each of these theories have studied the microeconomic decision to recruit or rebel. The Gates and Andvig chapter complements these with a broader, macroeconomic labor market view. Even though it is targeted at the narrower question of child soldiering, it is the first application of conventional labor economics I've seen in rebellion, and represents an important frontier. I sincerely hope this chapter is a prelude to a more ambitious, formal paper or book on rebel labor markets in general. We could learn a great deal about rebellion by beginning to unpack and systematize what drives labor demand in a rebel group, how the equilibrium changes in wars of short versus long duration, what happens in segmented rebellions and regular economic markets, or when governments and rebels compete for the same pool of recruits. In this sense, the chapter represents not just a unifying framework, but an important advance.

There is a second important advance in this volume. The case studies in chapter 7 by Jo Becker (on Burma, Sri Lanka, and Nepal), and in chapter 8 by Francisco Gutiérrez Sanin (on Colombia) carefully show how central are ideology and indoctrination to armed recruitment in general, and child soldiering in particular. The mainstream political science literature on who rebels and why has been nearly silent on the methods of indoctrination and the manufacture of ideology. Becker and Gutiérrez show the careful experimentation, successes, and failures of groups struggling to retain and motivate recruits. Children, their observation suggests, are more susceptible to this indoctrination. ${ }^{19}$

As it happens, my own data on child soldiers in northern Uganda support the same conclusion: the younger the recruits were forcibly recruited, the more likely they eventually expressed loyalty to the group, and the longer they stayed before attempting escape. ${ }^{20}$ Indeed, the ease of child indoctrination could be a necessary condition for their recruitment, for a 14-year-old eats food and uses weapons and could claim market wages nearly as expensive as that of a 19-year-old, but is inferior at a majority of military tasks. It is their responsiveness to indoctrination and coercion as an incentive that increases their marginal productivity and, with it, labor demand.

\section{The Soldier Turned Scholar: Dallaire on Child Soldiers}

Romeo Dallaire approaches the issue of child soldiering uniquely, from the perspective of one who encountered them at the point of his gun, or he at the point of theirs. What is most useful about his book is the military perspective so often absent from the academy and from advocates. Child soldiers must be treated as human beings, but we would do well to remember that from the perspective of armed leaders they are also a "weapons platform" that are attractive because they are low technology, cheap, expendable, and plentiful. ${ }^{21}$ Dallaire's candor is refreshing. Like some of the contributions in the Gates and Reich volume, however, such statements confuse the forces that influence labor supply, demand, and equilibrium choices.

One could argue that supply and demand curves and principal-agent theory dehumanize and overcomplicate. I argue that incentives matter, and we avoid their systematic analysis to our peril. But the absence of any overarching structure (a feature not just of these books, but the genre) means it is hard to hold the many competing theories in your head, weigh which are likely to be more important, and act accordingly. Seemingly arcane ideas like "elasticity" matter because, by definition, they tell us the sensitivity of the whole system to each moving partsurely a key ingredient in deciding what to do.

Like the Becker and Gutiérrez chapters mentioned earlier, Dallaire adds to the evidence that indoctrination and ideology are crucial to successful recruitment and retention. He does so in two revealing ways, one intentional, one not. The first draws on his own boyhood experiences in cadet camp, where (by his own account) they merely played at being soldiers. ${ }^{22} \mathrm{He}$ draws a stark contrast between his boyhood training and the unfortunate children put on the front lines of civil war "under the gun of inhuman adults." ${ }^{23}$ Certainly there is a huge difference between Canadian cadet camp and an army of drugged and wild children fighting on front lines. But it would be a mistake to forget that many of the most active child recruiters of the past two decades have been disciplined in rather conventional military forces. Also, cadet camps, even Canadian ones, are first and foremost institutions aimed at training, recruiting and, inescapably, indoctrinating children who, by Dallaire's own account, are more susceptible 
to influence and the manipulation of adults. Indeed, it was as an adolescent he claims to have found his lifelong vocation as a soldier. ${ }^{24}$

The second and more intentional illustration is his comparison of children across different Rwandan forces. He starts with the relatively disciplined and professional Rwandan Patriotic Front (RPF), an ethnically Tutsi-led group that invaded an ethnically Hutu-led Rwanda in 1990. As Dallaire experienced firsthand, the RPF front lines were manned by indoctrinated and relatively well-trained adolescents. He contrasts their regimented order with the approach taken by the Hutu extremists, who whipped disenfranchised adults and adolescents into an ideological frenzy, armed with machetes and trained to be "monstrous killing and mutilating machines." 25 The third comparison is with late joiners to the RPF-youth who were "cocky, gun happy and arrogant" and a threat to all in the fragile peace that descended post-war and post-genocide. ${ }^{26}$ These latecomer RPF recruits looked more like the unregimented Hutu extremists, and largely suited the evolving purpose of the rebel force.

The most important lesson I took from these examples is that the frenzy, the coercion, the training, the desensitization, and ultimately the genocidal acts were not irrational or inhuman, but sadly all too rational and (if history is any guide) all too human. There was method in the madness. I was surprised, therefore, that Dallaire struck a different tone elsewhere in the book, seeming to blame child soldiering on madness rather than method, as what happens "when states fail, when leaders go mad, when the chaos of violence takes over souls." ${ }^{27}$ He shows sympathy for the view that such armed groups have no ideology, no clear goals. ${ }^{28}$ What a contrast to his prime cases- the leaders of the RPF and the Hutu militants-who, if anything, were all too cool, ideological, and goal-oriented, to the detriment of the civilians around them.

This "new barbarism" language is common throughout the civil war literature. ${ }^{29}$ The idea of new, criminalized war without meaning is influential in P.W. Singer's chapter in the Gates and Reich volume as well. ${ }^{30}$ But the sentiment strikes me not only as misleading, but also harmful if we are serious about ending war and human rights abuses. ${ }^{31}$

The emphasis on criminal and non-ideological movements ignores the more reform-minded and ideological rebels that took power in (for example) Ethiopia, Uganda and Rwanda in the past two decades. It also ignores the sophisticated belief systems — spiritual and ethnic—so successfully used by groups like the Lord's Resistance Army in Uganda. Finally, it overlooks the parochial rebels who formed to defend their own communities in places such as Liberia and Sierra Leone. William Reno's review of African civil wars chronicles this diversity as well as any. ${ }^{32} \mathrm{To}$ be sure, many modern rebel groups have come to look more like bandits than ideological warriors, but one must consider the environment-as emphasized by Laia Bal- cells and Stathis Kalyvas an international system that fostered irregular warfare and, from the work of Jeffrey Herbst, states with fixed international borders but uncontrolled peripheries. ${ }^{33}$ Weak and dying rebel groups cannot be easily crushed by weak states, and these descend into banditry.

There is, no question, a dose of madness in many modern rebel leaders. But I am unconvinced this madness is new. To treat child recruitment as barbaric, and their motivations criminal or simple madness, is hazardous. It obscures the important fact that insurgent leaders will respond to incentives, including the threat of punishment.

Perhaps this talk of "barbarism" is more rhetoric than real belief, for neither Dallaire nor the contributors to the Gates and Reich volume bring the new barbarism into their policy prescriptions. The recommendations are many, but fall into a few main camps. One is quite obvious, but sadly elusive: work to end warfare and, where you cannot, provide military protection to civilians so that they cannot be abducted, terrorized, or have such poor security that it makes sense to pick up a gun.

There is also a near universal recognition of the need for prosecution and punishment of those who recruit child soldiers, and amnesty for the children themselves. Common sense and the formal theory converge here: the fear of punishment should preclude the recruitment of child soldiers in the future. Unfortunately, the ICC nearly bungled its first case, against Congolese warlord Thomas Lubanga for child soldiering, and he was nearly acquitted over faulty procedure ("Times Topics: Thomas Lubanga." In New York Times, January 12, 2011). Domestic courts in Africa have acquitted other child recruiters for lack of a solid and well-executed case. ${ }^{34}$ The world is in danger of establishing a custom of impunity, not punishment. This failure is the root of Gates and Reich's disappointment with the movement against child soldiering. ${ }^{35}$

Given both books' emphasis on indoctrination as a central explanation for child recruitment, however, I am puzzled by the general lack of attention given to counterindoctrination. In war zones where a child faces a one in twenty chance of abduction in a given year, it is striking how seldom radio stations and classrooms and community meetings are dedicated to information on rebel falsehoods and misconceptions, or training on escape. If we can drill American children in school about what to do in case of fire, why not in war zones prepare them against indoctrination or abduction? In northern Uganda, I witnessed such efforts emerge organically from civil society and concerned parents rather than from the international community or military. ${ }^{36}$ I wonder if part of our failure has been to think in terms of long-term development, or look to military solutions, rather than try to alter the fundamental naiveté and malleability of children that makes them so attractive as recruits.

Finally, given that warfare is unlikely to disappear, and its threat is omnipresent, a recurring prescription is to 
improve opportunities for children, and especially their economic and educational opportuities. This proposal makes sense in the framework of our labor markets model: to reduce child recruitment, increase their reservation wage, and lower the inelasticity of supply. This is a valuable goal. I have two quibbles with it, however. First, relieving poverty is a long-term solution and not what many, including contributors McClure and Retamal, demand-rapid and large-scale intervention when the need arises. ${ }^{37}$ Second, child soldier scholars and advocates emphasize the need for better reintegration services and targeting of child soldiers. ${ }^{38}$ This approach presumes that ex-combatants, especially children, are traumatized or outcast and require special services, even at the risk of stigmatization. But a growing body of rigorous research suggests that victims of violence - child or adult, combatant or not-are socially and psychologically resilient, and more often than not are welcomed by their communities. ${ }^{39}$ They are poor and uneducated, but not much more so than their noncombatant peers. ${ }^{40}$ And victims of violence, even when they are also perpetrators, may actually become more engaged and productive citizens, rather than sources of continuing violence. ${ }^{41}$

The evidence, while still fragmentary, makes a case for broad-based assistance that targets the traumatized, the poor, and the vulnerable rather than stigmatizing groups like child soldiers. Likewise, we may want to pause before pushing for advocacy and assistance for another stigmatized group: children born of wartime rape.

\section{The Scholar as Advocate: Carpenter and Children Born of War}

Whether or not advocates ought to target stigmatized groups with assistance, they certainly do in practice. Charli Carpenter asks why some groups get that attention and not others. Her answer has lessons for the politics of norm change and advocacy — one of the most novel and vibrant literatures in international relations of the past two decades.

Carpenter focuses on the case of Bosnia, where unknown thousands of babies were born of wartime rape perpetrated by enemy soldiers. Crucial in Bosnia is that the rape was not a byproduct of war but a strategic weapon-of terror, humiliation, and genocide. It is a weapon employed in other wars (though I see only Rwanda given as an example). ${ }^{42}$ Carpenter gives many more instances, however, of forced marriage and slavery, from Kuwait to Liberia, and Congo to East Timor. ${ }^{43}$ Carpenter's is an important question and case, for the norms literature has mainly focused on explaining successful norm diffusion. What about the norms that fail to diffuse? Ignoring these cases is a serious flaw in previous research designs.

Carpenter bases her work on four years of interviews with rights advocates, non-governmental organizations (NGOs), journalists, social workers, and government officials, mainly in Bosnia but also in UN and NGO hubs like New York and Geneva. Her focus, she explains, is on the international policy response and not the children, and so her data on the children themselves is secondary and fragmentary, from case worker studies. ${ }^{44}$ She also draws on a secondary literature from other war zones, including that from northern Uganda.

How do international norms spread, and what is the role of transnational advocacy networks? The standard account, typified by scholars such as Martha Finnemore, Kathryn Sikkink, and Margaret Keck, puts enormous emphasis on "moral entrepreneurs"-individuals and advocacy groups that push a particular agenda to a core group of opinion leaders, aiming for a cascade of new norm adoption and, eventually, internalization of the norm. ${ }^{45}$ Incentives and institutions matter, but the existence of the pushy moral entrepreneur is essential. What Carpenter shows is that moral entrepreneurs are not enough. Their goals must mesh with the discourse and interests of states and international organizations, or the message will not stick. Human rights and humanitarian issues do not simply exist, she explains, they are constructed by these entrepreneurs. If the construction doesn't fit collective interests, they will not be pursued. In this situation, the moral entrepreneurs themselves may not even emerge in force.

Why do children born or wartime rape fit so poorly with the interests of the international organizations in Bosnia? Reasons abound: the population is somewhat small, they are hard to identify and collect data on, and their problems are hard to solve; ${ }^{46}$ the Bosnian government is decentralized, suspicious of Western imperialism, and inattentive to gender; ${ }^{47}$ and the topic is politically sensitive and morally complicated, such that diplomatic organizations like the UN can be averse to such issues. ${ }^{48}$ These are technocratic excuses, for the most part, and Carpenter grants them a role. But she is unsatisfied. Other equally complicated issues get tackled all the time.

Carpenter wants to convince us that something more inhibits action. The framing of the issue matters, as do competing issues and narratives. To elevate the plight of the child, she argues, would diminish two other powerful symbols and narratives: the wrong committed against raped women, and the wrong against the ethnic group targeted for cleansing. Children, she suggests, are the embodiment of any national identity. Forced impregnation by an enemy is a symbol of aggression and humiliation. These children are a symbol of past aggression, and can be a powerful tool for rebuilding a postwar order and identity. ${ }^{49}$ Even if not used consciously as a tool, the new society has an interest in minimizing their profile or presence, if only because of discomfort or ambivalence. ${ }^{50}$ All of these factors raise the difficulty of organizing around the issue. ${ }^{51}$

This "competing interests" thesis is important, and deserves to be considered in every case of norm diffusion moving forward. It has parallels to recent studies of norm diffusion at the subnational level, and how success varies 
according to the fit between local and international norms and institutions. ${ }^{52}$ But I hesitate to give it primary position in the case of children born of war.

First, I am not convinced that the "competing narrative" explanation is strictly necessary. The more banal and technocratic explanations strike me as sufficient to deter a UN agency or international organization from intervention. Perhaps the issues faced by the children, the small population, and the difficulty in counting and reaching them, were enough to deter action. There are innumerable vulnerable groups, and international organizations seem to have room for only so many causes célèbres. Moreover, I think Carpenter downplays too much a legitimate UN and NGO concern that targeting children born of wartime rape would stigmatize, and possibly hurt more than help. In my own experience, agencies like UNICEF have (until recently) not been concerned enough with stigmatization, and they have targeted child soldiers and "AIDS orphans" with zeal in Liberia and northern Uganda, where I have worked the most. But in neither place was there great stigma associated with AIDS or rebel abduction, when nearly every family unit has been affected. It sounds as though the stigma concern is much more acute in Bosnia. A more comparative study, one that compared equally "complicated" issues and how their construction matches or not the existing interests, would provide a stronger test of Carpenter's theory. I hope to see it in future work.

Second, my experience working with former child soldiers and forced wives in Liberia and northern Uganda has made me cautious of claims that particular groups experience more acute abuse, neglect, and discriminationexperiences Carpenter assigns to Bosnian children born of rape. ${ }^{53}$ It seems there are no data, and certainly no systematic data, on children born of wartime rape in Bosnia. Yet the limited rigorous data we have on waraffected youth suggest that stigma is lower than feared, and poverty, while extreme, is comparable to that of their non-combatant peers (at least in a handful of African cases). This was the outcome I observed in communities in northern Uganda, who deliberately embraced rather than excluded their stolen children, including children forcibly born. Some returning women and children are ostracized, but systematic data revealed (somewhat unexpectedly) they are the exception rather than the rule. ${ }^{54}$ This pattern of resilience and integration has been observed in other regions, including West Africa. ${ }^{55}$ Policymakers' worst fears were not realized, and in some cases the opposite appears to be true.

This underlines the importance of systematic and representative data, including data on the counterfactual, for good advocacy and good policy. James Pugel's analysis of Liberian ex-combatant survey data in the Gates and Reich book exemplifies what is possible. ${ }^{56}$ With little time, limited funds, and the help of a UN agency, he fielded a rapid survey of demobilizing combatants, modeled after Macartan Humphreys and Jeremy Weinstein's pioneering survey of ex-combatants in Sierra Leone. ${ }^{57}$ There should be more efforts like Pugel's.

Collecting such data will take unusual precaution and care, however, especially when dealing with stigmatized populations like those in Bosnia. Representative, populationbased surveys that screen and then target sensitive subpopulations probably offer the best prospect of information on stigmatized population, an approach that worked well for my collaborator Jeannie Annan and me in our search for data on child soldiers and forced wives in Uganda. ${ }^{58}$ Barry Ames' methodological chapter in the Gates and Reich book has important lessons for data collection in war, and not just on children. ${ }^{59}$ I hope Carpenter's book spurs this important next step.

\section{Social Science and Social Change}

Many of us - including nearly all the authors mentioned in this essay-enter academia with a passion for social change. You quickly learn, however, not to advertise these motives. Policy relevance helps frame a paper, but cannot be the main basis of a serious journal. Carpenter tells a story in her Preface that, to me, sounds familiar. On the academic job circuit, she writes, "I blurted out once that year, in a conversation that probably lost me a job offer, that my next book might be about children of war. A famous political scientist coolly asked me why was this theoretically significant. It took years for a persuasive answer to that question to materialize." 60

I used to resent this insistence on theoretical significance and politics as the end in itself. Why can't we respectably apply social science methods to explain policy? What I've come to realize is that the "why is this theoretically significant?" question is not an obstacle I must overcome to gain academic esteem and publish in top journals, but rather is fundamental to that goal of social change. This is a point young scholars, especially Ph.D. students, ought to hear more often (I wish someone had told me). The big questions and theory are important precisely because they tell us something fundamental about how politics and political beings work. This is what gives a study generalizability, and with that the power for much broader change.

Let me conclude with two examples from my own work, not to trumpet my successes, but rather to illustrate my failures and regrets (for I would hesitate to illustrate anyone else's mistakes so frankly). By 2008, my work on children impacted by war spurred an interest in post-war recovery and stabilization. How to raise employment and incomes after war, I began to ask, and would poverty reduction reduce the risk of social instability? Like many, I caught the randomized control trial bug. I launched evaluations of a post-conflict cash transfer program in northern Uganda, and an ex-combatant reintegration program in 
rural Liberia. ${ }^{61}$ In both cases, preliminary results suggest that the programs decreased poverty and reduced male aggression and, in the Liberia case, lowered the chances of recruitment into neighboring countries' conflicts.

These are important findings, you might think. But what have we learned about poverty and violence? The answer is unclear. Each program suggested a hodgepodge of activities (like training, physical capital, and some form of committed investment). This makes it hard to identify the constraints people faced and to test alternative theories of poverty - surely the most important thing I could have learned. As for violence, why are these men less aggressive? Because the treatment increases their opportunity cost of violence? Lessens their stress? Further removes them from mobilization networks? Or mitigates feelings of deprivation and injustice? These are the fundamental theoretical questions we must answer. They also happen to be the answers most important to better policy and programs. The research design, however, makes them difficult to answer.

As it happens, it's possible to answer these questions in part, and to weigh in on central theoretical debates on poverty and violence-or so I am attempting. And my more recent projects avoid the same mistakes. If only, I sometimes wish, a famous scholar coolly asked me in 2008 why my work was theoretically significant. It is now 2012, and we do ourselves, our students, and public policy a favor by asking that precise question.

\section{Notes}

1 Gates and Reich 2010, 39-51.

2 United Nations 2011.

3 Human Security Report Project 2008.

4 Coalition to Stop the Use of Child Soldiers 2008.

5 United Nations 2011.

6 Kaplan 1994, Gettleman 2010, Kaldor 1999, Nordstrom 2004.

7 Gates and Reich 2010, 4.

8 Ibid., 50-51.

9 Reich 2010.

10 Human Security Report Project 2008.

11 Interview with Radhika Coomaraswamy, New York, March 30, 2011; United Nations 2011.

12 Gates and Reich 2010, 93-107.

13 Lewis 1954.

14 See, for instance, Singer in Gates and Reich 2010, 105, 107.

15 Beber and Blattman 2011.

16 Personal communication with Scott Gates, February 16, 2012.

17 Lichbach 1995, Wood 2003, Gates 2002, Weinstein 2007, Beber and Blattman 2011.

18 Gates 2002.

19 Gates and Reich 2010, 114-117, 138-140.
20 Beber and Blattman 2011.

21 Dallaire 2011, 12-13, 117.

22 Ibid., 24-28.

23 Ibid., 29.

24 Ibid., 26.

25 Ibid., 41.

26 Ibid., 43.

27 Ibid., 105.

28 Ibid., 115.

29 Richards 1996.

30 Gates and Reich 2010, 102-104.

31 See Kalyvas 2001 on the validity of the "new" versus "old" distinction.

32 Reno 2011.

33 Balcells and Kalyvas 2010; Herbst 2000, 2004;

Reno 2011.

34 Dallaire 2011, 124.

35 Personal communication with Scott Gates, February 16, 2012.

36 Beber and Blattman 2011.

37 Gates and Reich 2010, 225.

38 See the literature discussed by Dallaire 2011, 165-182.

39 E.g., Annan and Patel 2009; Humphreys and Weinstein 2007; Wessells 2006.

40 E.g., Blattman and Annan 2010; Tajima 2009.

41 E.g., Bellows and Miguel 2009; Blattman 2009;

Voors et al. forthcoming.

42 Carpenter 2010, 17.

43 Ibid., 18.

44 Ibid., 9-13.

45 E.g., Finnemore and Sikkink 1998; Keck and Sikkink 1998.

46 Carpenter 2010, 48-52.

47 Ibid., 112.

48 Ibid., 132.

49 Ibid., 143.

50 Ibid., 139.

51 Ibid., 188-189.

52 E.g. see Karisa Cloward 2010 on female genital mutilation.

53 Carpenter 2010, 17.

54 Annan et al. 2011

55 See Wessells 2006; Humphreys and Weinstein 2007; Annan and Patel 2009. Difficult reintegration is common, but it is the minority who seem to experience high levels of rejection.

56 Gates and Reich 2010, 160-182.

57 Humphreys and Weinstein 2007.

58 Blattman and Annan 2010.

59 Gates and Reich 2010, 14-26.

60 Carpenter 2010, xvi.

61 These studies are ongoing. For a study description and preliminary results, see Annan and Blattman 2011 and Blattman, Fiala, and Martinez 2011. 


\section{References}

Annan, Jeannie, and Christopher Blattman. 2011. "Reintegrating and Employing High Risk Youth in Liberia: Lessons from a Randomized Evaluation of a Landmine Action Agricultural Training Program for Ex-Combatants." New Haven, CT: Innovations for Poverty Action. https://www.poverty-action.org/sites/ default/files/lma_impacts_report___final.pdf, accessed February 17, 2012.

Annan, Jeannie, Christopher Blattman, Dyan Mazurana, and Khristopher Carlson. 2011. "Civil War, Reintegration, and Gender in Northern Uganda." Journal of Conflict Resolution 55(6): 877-908.

Annan, Jeannie, and Ana Cutter Patel. 2009. "Critical Issues and Lessons in Social Reintegration: Balancing Justice, Psychological Well Being, and Community Reconciliation." In International DDR Congress $(C I D D R)$. Cartagena, Colombia.

Balcells, Laia, and Stathis N. Kalyvas. 2010. "International System and Technologies of Rebellion: How the Cold War Shaped Internal Conflict." American Political Science Review 104(3): 415-29.

Beber, Bernd, and Christopher Blattman. 2011. "The Logic of Child Soldiering and Coercion." Households in Conflict Network Working Paper 72. http://www. hicn.org/papers/wp72.pdf, accessed February 17, 2012.

Bellows, John, and Edward Miguel. 2009. "War and Local Collective Action in Sierra Leone." Journal of Public Economics 93(11-12): 1144-57.

Blattman, Christopher. 2009. "From Violence to Voting: War and Political Participation in Uganda." American Political Science Review 103(2): 231-47.

Blattman, Christopher, and Jeannie Annan. 2010. "The Consequences of Child Soldiering." Review of Economics and Statistics 92(4): 882-98.

Blattman, Christopher, Nathan Fiala, and Sebastian Martinez. 2011. "Can Employment Programs Reduce Poverty and Social Instability? Experimental Evidence from an Aid Program in Uganda." Unpublished working paper.

Carpenter, R. Charli. 2010. Forgetting Children Born of War: Setting the Human Rights Agenda in Bosnia and Beyond. New York: Columbia University Press.

Cloward, Karisa Tritz. 2010. "When Norms Collide: Micro-Level Responses to the Transnational Campaign Against Gender-Based Violence." Ph.D. diss. Yale University.

Coalition to Stop the Use of Child Soldiers. 2008. "Child Soldiers Global Report 2008." London. http://www.childsoldiersglobalreport.org/, accessed February 17, 2012.

Dallaire, Roméo. 2011. They Fight Like Soldiers, They Die Like Children: The Global Quest to Eradicate the Use of Child Soldiers. New York: Walker \& Company.
Finnemore, Martha, and Kathryn Sikkink. 1998. "International Norm Dynamics and Political Change." International Organization 52(4): 887-917.

Gates, Scott. 2002. "Recruitment and Allegiance: The Microfoundations of Rebellion." Journal of Conflict Resolution 46(1): 111-30.

Gates, Scott, and Simon Reich. 2010. Child Soldiers in the Age of Fractured States. Pittsburgh: University of Pittsburgh Press.

Gettleman, Jeffrey. 2010. "Africa’s Forever Wars: Why the Continent's Conflicts Never End." Foreign Policy 178. http://www.foreignpolicy.com/articles/2010/02/ 22/africas_forever_wars, accessed February 17, 2012.

Herbst, Jeffrey. 2000. States and Power in Africa: Comparative Lessons in Authority and Control. Princeton: Princeton University Press.

- 2004. "African Militaries and Rebellion: The Political Economy of Threat and Combat Effectiveness." Journal of Peace Research 41(3): 357-69.

Human Security Report Project. 2008. "Human Security Brief 2007." Ed. Andrew Mack and Zoe Nielsen. Vancouver: Simon Fraser University.

Humphreys, Macartan, and Jeremy M. Weinstein. 2007. "Demobilization and Reintegration." Journal of Conflict Resolution 51(4): 531-67.

Kaldor, Mary. 1999. New and Old Wars: Organized Violence in a Global Era. Cambridge, UK: Polity Press.

Kalyvas, Stathis N. 2001. “'New' and 'Old' Civil Wars: A Valid Distinction?” World Politics 54: 99-118.

Kaplan, Robert D. 1994. “The Coming Anarchy.” Atlantic Monthly 273(2): 44-76.

Keck, Margaret E., and Kathryn Sikkink. 1998. Activists Beyond Borders: Advocacy Networks in International Politics. Ithaca, NY: Cornell University Press.

Lewis, W. Arthur. 1954. "Economic Development with Unlimited Supplies of Labor." The Manchester School 22(2): 139-91.

Lichbach, Mark I. 1995. The Rebel's Dilemma. Ann Arbor, MI: University of Michigan Press.

Nordstrom, Carolyn. 2004. Shadows of War: Violence, Power, and International Profiteering in the Twenty-first Century. Berkeley: University of California Press.

Reich, Simon. 2010. Global Norms, American Sponsorship and the Emerging Patterns of World Politics. New York: Palgrave MacMillan.

Reno, William. 2011. Warfare in Independent Africa. New York: Cambridge University Press.

Richards, Paul. 1996. Fighting for the Rain Forests: War, Youth, and Resources in Sierra Leone. Portsmouth, NH: Heinemann.

Tajima, Yuhki. 2009. "Background Paper on Economic Reintegration." In International DDR Congress (CIDDR) Cartagena, Colombia. 
United Nations. 2011. "Report of the Special Representative of the Secretary General for Children and Armed Conflict." New York: United Nations General Assembly.

Voors, M.J., E.E.M. Nillesen, E.H. Bulte, B.W. Lensink, Philip Verwimp, and D.P. van Soest. Forthcoming. "Violent Conflict and Behavior: a Field

Experiment in Burundi." American Economic Review.
Weinstein, Jeremy M. 2007. Inside Rebellion: The Politics of Insurgent Violence. New York: Cambridge University Press.

Wessells, Michael. 2006. Child Soldiers: From Violence to Protection. Cambridge, MA: Harvard University Press. Wood, Elisabeth J. 2003. Insurgent Collective Action and Civil War in El Salvador. New York: Cambridge University Press. 